\title{
Different phenotypes in dermatomyositis associated with anti-MDA5 antibody
}

\author{
Study of 121 cases
}

Yves Allenbach, MD, PhD,* Yurdagul Uzunhan, MD, PhD,* Ségolène Toquet, MD,* Gaëlle Leroux, MD, Laure Gallay, MD, Alicia Marquet, MD, Alain Meyer, MD, PhD, Constance Guillaud, MD, Nicolas Limal, MD, Frédéric Gagnadoux, MD, PhD, Baptiste Hervier, MD, PhD, Raphaël Borie, MD, PhD, Christophe Deligny, MD, PhD, Benjamin Terrier, MD, PhD, Alice Berezne, MD, Sylvain Audia, MD, PhD, Nicolas Champtiaux, MD, PhD, Hervé Devilliers, MD, PhD, Nicol Voermans, MD, Elizabeth Diot, MD, Amélie Servettaz, MD, PhD, Thierry Marhadour, MD, Vincent Castelain, MD, PhD, Sébastien Humbert, MD, Claire Blanchard-Delaunay, MD, Nathalie Tieulie, MD, PhD, Pierre Charles, MD, Magdalena Gerin, MD, Arsène Mekinian, MD, PhD, Pascaline Priou, MD, Jean Claude Meurice, MD, PhD, Abdellatif Tazi, MD, PhD, Vincent Cottin, MD, PhD, Makoto Miyara, MD, PhD, Benjamin Grange, MD, Dominique Israël-Biet, MD, PhD, Sophie Phin-Huynh, MD, Camille Bron, MD, Luc De Saint Martin, MD, Nicole Fabien, MD, Kubéraka Mariampillai, MD, Hilario Nunes, MD, PhD, $†$ and Olivier Benveniste, MD, PhD, $†$ the French Myositis Network

Neurology ${ }^{\circledR}$ 2020;95:1-9. doi:10.1212/WNL.0000000000009727

\begin{abstract}
Objectives

The predominance of extramuscular manifestations (e.g., skin rash, arthralgia, interstitial lung disease [ILD]) as well as the low frequency of muscle signs in anti-melanoma differentiation-associated gene 5 antibody-positive (antiMDA5+) dermatomyositis caused us to question the term myositis-specific antibody for the anti-MDA5 antibody, as well as the homogeneity of the disease.
\end{abstract}

\section{Methods}

To characterize the anti-MDA5+ phenotype, an unsupervised analysis was performed on anti-MDA5+ patients ( $\mathrm{n}=83 / 121)$ and compared to a group of patients with myositis without anti-MDA5 antibody (anti-MDA5-; $\mathrm{n}=190 / 201)$ based on selected variables, collected retrospectively, without any missing data.

\section{Results}

Within anti-MDA5+ patients $(\mathrm{n}=83), 3$ subgroups were identified. One group (18.1\%) corresponded to patients with a rapidly progressive ILD (93.3\%; $p<0.0001$ across all) and a very high mortality rate. The second subgroup (55.4\%) corresponded to patients with pure dermato-rheumatologic symptoms (arthralgia; 82.6\%; $p<0.01$ ) and a good prognosis. The third corresponded to patients, mainly male $(72.7 \% ; p<0.0001)$, with severe skin vasculopathy, frequent signs of myositis (proximal weakness: 68.2\%; $p<0.0001$ ), and an intermediate prognosis. Raynaud phenomenon, arthralgia/arthritis, and sex permit the cluster appurtenance (83.3\% correct estimation). Nevertheless, an unsupervised analysis confirmed that antiMDA5 antibody delineates an independent group of patients (e.g., dermatomyositis skin rash, skin ulcers, calcinosis, mechanic's hands, ILD, arthralgia/arthritis, and high mortality rate) distinct from anti-MDA5- patients with myositis.

\section{Conclusion}

Anti-MDA5+ patients have a systemic syndrome distinct from other patients with myositis. Three subgroups with different prognosis exist.

\author{
Correspondence \\ Dr. Allenbach \\ yves.allenbach@aphp.fr
}

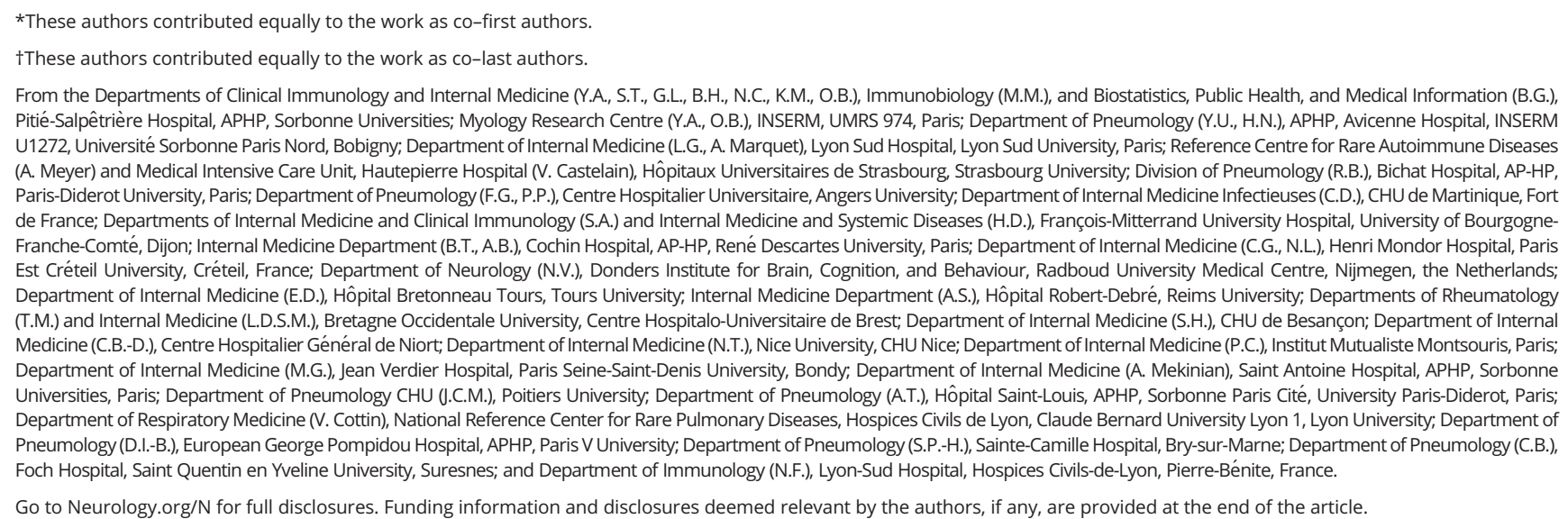




\section{Glossary}

CK = creatine kinase; $\mathbf{D M}=$ dermatomyositis; ENMC = European NeuroMusclar Center; $\mathbf{I C U}=$ intensive care unit; ILD = interstitial lung disease; MDA5 = melanoma differentiation-associated gene 5; RP-ILD = rapidly progressive interstitial lung disease.

Dermatomyositis (DM) is a heterogeneous group of autoimmune diseases, including disorders limited to the skin of patients, with extracutaneous manifestations, such as muscle, articular or pulmonary lesions, and sometimes with an association with malignancy. ${ }^{1}$ Myositis-specific autoantibodies permit the delineation of homogenous subgroups of $\mathrm{DM} .{ }^{1,2} \mathrm{DM}$ associated with anti-melanoma differentiation-associated gene 5 antibody (anti-MDA5+) is typically characterized by the presence of a DM skin rash and polyarthralgia and interstitial lung disease (ILD), whereas the clinical signs of myositis are frequently absent. ${ }^{1,3-5}$ Anti-MDA5+ DM has a high mortality rate related to the presence of rapidly progressive ILD (RP-ILD). ${ }^{1}$

The predominance and the variety of the extramuscular manifestations, as well as the absence of muscle symptoms, calls into question the term myositis-specific antibody for anti-MDA5 antibodies.

The anti-MDA5 antibody was identified in $2009,{ }^{5}$ and a limited number of case reports and case series have been reported. Knowledge of the precise clinical phenotype and the prognosis of anti-MDA5+ patients is necessary to improve the management of this potentially severe disease.

To characterize the anti-MDA5+ phenotype, we analyzed the characteristics of a large group of patients $(\mathrm{n}=121)$ and performed unsupervised analysis to detect subgroups with different prognoses among anti-MDA5+ patients. We also compared anti-MDA5 + patients with a group of myositis patients without anti-MDA5 antibody (anti-MDA5-; $n=201$ ) to confirm the specificity of the phenotype.

\section{Methods}

\section{Patients}

Anti-MDA5+ patients were included in the study if they presented any of the following or a combination thereof: a DM skin rash compatible with DM, according to the European NeuroMusclar Center (ENMC) criteria $^{6}$ or Sontheimer criteria $^{7}$; myositis (pathologic features showing the presence of inflammatory infiltrates); arthralgia; or ILD, without other etiology. Anti-MDA5 antibody detection was performed using line-immunoassays (Euroimmun [Germany] or D-Tek [Belgium]). This multicenter observational study was performed on data available from 37 medical centers in France from 2011 to 2017. Medical records were reviewed retrospectively (Y.A., S.T., G.L., and Y.U.) to collect clinical, laboratory, and imaging data. ILD was defined based on CT imaging studies and RP-ILD was defined by the acute onset and rapid worsening within 3 months of the onset of respiratory symptoms leading to severe hypoxia $\leq 60 \mathrm{~mm} \mathrm{Hg}$. Early mortality was defined by death within 3 months of the diagnosis. As a control, a cohort of anti-MDA5- patients with myositis was used. All of the controls had myositis defined based on ENMC $^{6}$ or Bohan and Peter criteria ${ }^{8}$ and were followed in one center (Pitié-Salpêtrière Hospital). The controls' characteristics are detailed in table e-1 (doi.org/10.5061/dryad.t39c4k1).

\section{Standard protocol approvals, registrations, and patient consents}

Agreement for the study was obtained from the French Ministry of Research (CCTIRS no. 14.323 and AC-20131868) and the study was approved by the Research Ethics Committee of the Pitié-Salpêtrière Hospital (Paris, France).

\section{Statistics}

Quantitative data (median [interquartile range]) and qualitative data (frequency and percentage) were described. Unsupervised descriptive methods of statistical learning were used to analyze either the anti-MDA5+ patients or the global cohort of patients with myositis (anti-MDA5+ and antiMDA5-). A multiple correspondence analysis and hierarchical cluster analysis were used to resume the dataset and aggregate patients in subgroups, as previously reported. ${ }^{9}$ Only patients with an exhaustive set of data were included for the unsupervised analysis. The clustering of patients was unsupervised using Euclidean distance and the Ward agglomerative method. $\mathrm{V}$ test $p$ values are represented for the variables that participated in the multidimensional analyses (see supplemental tables, doi.org/10.5061/dryad.t39c4k1). ${ }^{10}$ In addition, the Wilcoxon test was used to compare quantitative data and anti-MDA5 status (positive or negative), and Fisher exact test was used for qualitative data in the different groups (anti-MDA5 status [positive or negative]) or global association with the clusters obtained by hierarchical cluster analysis (tables 1 and 2).

To construct a decisional algorithm tree to position the patients in a cluster, we used classification and regression trees. A $p$ value $<0.05$ was considered significant. For the survival analysis, Kaplan-Meier curves were performed on different patient subgroups and compared using log-rank tests. Statistical analyses were performed ( $\mathrm{R}$ version 3.4.0 software and GraphPad Prism software).

\section{Data availability}

All supplementary data are available from the Dryad digital repository (doi.org/10.5061/dryad.t39c4k1). Further anonymized 
Table 1 Characteristics of 3 groups of anti-melanoma differentiation-associated gene 5 antibody-positive (anti-MDA5+) patients

\begin{tabular}{|c|c|c|c|c|}
\hline & Cluster $1(n=15)$ & Cluster $2(n=46)$ & Cluster $3(n=22)$ & $p$ Value \\
\hline \multicolumn{5}{|l|}{$\operatorname{Sex}^{a}$} \\
\hline Women & $11(73.3)$ & $38(82.6)$ & $6(27.3)$ & $<0.0001$ \\
\hline Men & $4(26.7)$ & $8(17.4)$ & $16(72.7)$ & \\
\hline \multicolumn{5}{|l|}{ Ethnicity $^{a}$} \\
\hline Caucasian & $6(40)$ & $23(50)$ & $12(54.5)$ & 0.67 \\
\hline African & $7(46.7)$ & $20(43.5)$ & $10(45.4)$ & \\
\hline Asian & $2(13.3)$ & $2(4.5)$ & $0(0)$ & \\
\hline Hispanic & $0(0)$ & $1(2.2)$ & $0(0)$ & \\
\hline \multicolumn{5}{|l|}{ General condition/inflammation } \\
\hline Fever & $6(40)$ & $14(30.4)$ & $9(42.9)$ & 0.57 \\
\hline Deterioration of general condition ${ }^{a}$ & $14(93.3)$ & $30(65.2)$ & $10(45.4)$ & 0.008 \\
\hline CRP or ESR increase & $7(58.3)$ & $18(41.9)$ & $9(47.4)$ & 0.62 \\
\hline \multicolumn{5}{|l|}{ Skin changes } \\
\hline Skin lesions ${ }^{a}$ & $15(100)$ & $38(82.6)$ & $21(95.4)$ & 0.16 \\
\hline Mechanic's hands ${ }^{a}$ & $11(73.3)$ & $20(43.5)$ & $3(13.6)$ & 0.0011 \\
\hline Typical DM skin rasha & $12(80)$ & $31(67.4)$ & $17(77.3)$ & 0.63 \\
\hline Raynaud phenomenon ${ }^{a}$ & $1(6.7)$ & $5(10.9)^{a}$ & $18(81.8)$ & $<0.0001$ \\
\hline Skin ulcers ${ }^{a}$ & $4(26.7)$ & $17(37)$ & $17(77.3)$ & 0.002 \\
\hline Digital necrosis $^{a}$ & $0(0)$ & $2(4.3)$ & $7(31.8)$ & 0.002 \\
\hline Calcinosis $^{a}$ & $0(0)$ & $2(4.3)$ & $5(22.7)$ & 0.02 \\
\hline Skin sclerosis $^{a}$ & $1(6.7)$ & $2(4.3)$ & $5(22.7)$ & 0.05 \\
\hline \multicolumn{5}{|l|}{ Muscular manifestations } \\
\hline Proximal weakness $^{a}$ & $4(26.7)$ & $7(15.2)^{a}$ & $15(68.2)$ & 0.0001 \\
\hline $\operatorname{MRC} \leq 3^{a}$ & $0(0)$ & $1(2.3)$ & $5(26.3)$ & 0.003 \\
\hline Increased CK level ${ }^{\mathrm{a}}$ & $10(66.7)$ & $10(21.7)$ & $14(63.6)$ & 0.0004 \\
\hline $\mathrm{CK}>160 \mathrm{IU} / \mathrm{L}$ and $<800 \mathrm{IU} / \mathrm{L}^{\mathrm{a}}$ & $10(66.7)$ & $11(24)$ & $6(27.3)$ & \\
\hline$>800 \mathrm{IU} / \mathrm{L}^{\mathrm{a}}$ & $1(6.7)$ & $0(0)$ & $8(36.4)$ & \\
\hline Myositis on muscle biopsy & $2(50)$ & $12(52.2)$ & $9(56.2)$ & 1 \\
\hline \multicolumn{5}{|l|}{ Lung manifestations } \\
\hline Dyspnea $^{a}$ & $15(100)$ & $28(60.9)$ & $10(45.4)$ & 0.0008 \\
\hline ILD $^{a}$ & $15(100)$ & $38(82.6)$ & $11(50)$ & 0.0008 \\
\hline RP-ILD ${ }^{a}$ & $14(93.3)$ & $8(17.4)$ & $5(22.7)$ & $<0.0001$ \\
\hline $\mathrm{PaO}_{2}<60 \mathrm{~mm} \mathrm{Hg}$ & $13(92.8)$ & $8(23.6)$ & $8(57.1)$ & $<0.0001$ \\
\hline \multicolumn{5}{|l|}{ Rheumatologic manifestations } \\
\hline Arthritis/arthralgia $^{a}$ & $4(26.7)$ & $38(82.6)$ & $17(77.3)$ & 0.0003 \\
\hline Synovitis $^{a}$ & $1(6.7)$ & $17(37)$ & $9(41)$ & 0.0479 \\
\hline RF or anti-CCP antibody & $3(27.7)$ & $5(13.5)$ & $4(21)$ & 0.46 \\
\hline
\end{tabular}


Table 1 Characteristics of 3 groups of anti-melanoma differentiation-associated gene 5 antibody-positive (anti-MDA5+) patients (continued)

\begin{tabular}{|c|c|c|c|c|}
\hline & Cluster $1(n=15)$ & Cluster $2(n=46)$ & Cluster $3(n=22)$ & $p$ Value \\
\hline \multicolumn{5}{|l|}{ Outcomes } \\
\hline $\mathrm{ICU}^{\mathrm{a}}$ & $13(86.7)$ & $5(10.9)^{a}$ & $8(36.4)$ & $<0.0001$ \\
\hline Death within 3 months ${ }^{a}$ & $12(80)$ & $0(0)^{a}$ & $1(4.5)$ & $<0.0001$ \\
\hline \multicolumn{5}{|l|}{ Miscellaneous } \\
\hline Malignancy $^{a}$ & $1(6.7)$ & $2(4.3)$ & $1(4.5)$ & 1 \\
\hline Lymphadenopathy & $5(38.5)$ & $15(33.3)$ & $4(19)$ & 0.4 \\
\hline Seritis & $0(0)$ & $7(16.7)$ & $4(18.2)$ & 0.27 \\
\hline Increased liver enzymes & $8(66.7)$ & $16(40)$ & $11(61.1)$ & 0.18 \\
\hline Leukopenia & $2(16.7)$ & $13(31.7)$ & $3(15)$ & 0.32 \\
\hline ANA & $5(41.7)$ & $21(55.3)$ & $11(57.9)$ & 0.72 \\
\hline
\end{tabular}

Abbreviations: ANA = antinuclear antibody; anti-CCP = anti-cyclic citrullinated peptide antibody; $\mathrm{CK}=$ creatine kinase; $\mathrm{CRP}=\mathrm{C}$-reactive protein; DM = dermatomyositis; ESR = erythrocyte sedimentation rate; ICU = intensive care unit; ILD = interstitial lung disease; MRC = Medical Research Council scale; RF = rheumatoid factor; RP-ILD = rapidly progressive interstitial lung disease.

Values are $n(\%)$.

${ }^{a}$ Variables used in the unsupervised analysis permitting us to identify the 3 clusters. The other variables (not used for the clustering, because not available for all anti-MDA5+ patients) were positioned in the different clusters.

data can be made available to qualified investigators upon request to the corresponding author.

\section{Results}

\section{Three MDA5+ patient subgroups}

Anti-MDA5 + patients $(\mathrm{n}=121)$ were mainly female, 49 years old (34-58), and Caucasian, but African origin was also frequent. As expected, most of the patients had a DM skin rash (71.2\%), ILD (76.5\%), and arthralgia (69\%), whereas only one-third of patients had muscle weakness (table e-2, doi.org/ 10.5061 /dryad.t39c4k1). Of note, 2 patients had concomitant myocarditis with severe cardiac failure.

We aimed to identify the phenotype variations within the antiMDA5+ group $(n=83 / 121)$. The unsupervised hierarchical analysis tree that we positioned on the factorial map showed 3 clusters (figure 1, A and B). The characteristics of each cluster are reported in table 1.

Cluster $1(18.1 \% ; n=15)$ corresponded to patients with very severe lung disease (RP-ILD cluster). All patients had ILD, and all but one had RP-ILD (93.3\%; V test $p<0.0001$ ). Patients in this cluster were admitted to the intensive care unit (ICU) in $86.7 \%$ of cases $(p<0.0001)$. The early mortality rate was high $(80 \%$; V test $p<0.0001)$. The other main characteristic was that these patients frequently had mechanic's hands (73.3\%; V test $p=0.006)$.

Cluster $2(55.4 \% ; \mathrm{n}=46)$ corresponds to a pure dermatorheumatologic pattern (rheumatoid cluster). As for the RP-ILD cluster, patients in cluster 2 were mainly women and less frequently had skin lesions ( $82.6 \%$; V test $p=0.03)$, digital necrosis $(4.35 \% ; p=0.04)$, and the Raynaud phenomenon $(10.9 \%$; V test $p<0.0001)$ (table 1$)$. Most patients in cluster 2 complained of arthralgia or arthritis $(82.6 \%$; V test $p=0.01$ ). Signs of myositis (muscle weakness $15.2 \%$; V test $p=0.0005$ and increased creatine kinase $[\mathrm{CK}]$ level $21.7 \%$; V test $p<0.0001)$, as well as RP-ILD $(17.4 \%$; V test $p=0.001)$, were infrequent, and no early death occurred in this group (V test $p<0.0001)$.

Cluster $3(26.5 \% ; n=22)$ corresponded to patients with severe skin vasculopathy and an intermediate prognosis (vasculopathic cluster). Patients here were mainly male (72.7\%; V test $p<0.0001)$. In addition to the classical DM skin rash, those patients frequently harbored signs of skin vasculopathy with the Raynaud phenomenon $(81.8 \%$; V test $p<0.0001)$, skin ulcers (77.3\%; V test $p=0.0006)$, digital necrosis $(31.8 \% ; p=0.001)$, and calcinosis $(22.7 \%$; $V$ test $p$ $=0.01)$. In addition, most patients had proximal weakness (68.2\%; V test $p<0.0001)$ with increased CK levels in $63.6 \%$ (V test; $p<0.0001$ ). Some of the patients in cluster 3 had RP-ILD (22.7\%), and the early mortality rate was low ( $4.5 \%$ in the vasculopathic cluster).

\section{Three different MDA5+ patients prognoses}

We next analyzed the long-term survival of anti-MDA5+ patients depending on the 3 clusters (figure $2 \mathrm{~A}$ ). The analysis clearly confirmed a different prognosis between the clusters. The RP-ILD cluster had a very high mortality rate compared to patients in the rheumatic and vasculopathic clusters $(p<$ 
Table 2 Comparison of anti-melanoma differentiationassociated gene 5 antibody-positive (antiMDA5+) vs anti-MDA5- patients with myositis

\begin{tabular}{llll}
\hline & $\begin{array}{l}\text { Anti-MDA5- } \\
(\mathbf{n}=\mathbf{2 0 1})\end{array}$ & $\begin{array}{l}\text { Anti-MDA5+ } \\
(\mathbf{n}=\mathbf{1 2 1})\end{array}$ & $\boldsymbol{p}$ Value \\
\hline Sex & & & \\
\hline Male & $56(27.9)$ & $40(33.1)$ & 0.3889 \\
\hline Ethnicity & & & \\
\hline Caucasian & $144(71.6)$ & $56(48.3)$ & $<0.0001$ \\
\hline African & $30(14.9)$ & $50(43.1)$ & \\
\hline Asian & $6(3)$ & $8(6.9)$ & \\
\hline Others & $21(10.4)$ & $2(1.7)$ & $<0.0001$ \\
\hline Skin & & & $<0.0001$ \\
\hline Skin lesions & $129(64.2)$ & $105(87.5)$ & $<0.0001$ \\
\hline Typical DM skin rash & $54(26.9)$ & $84(70)$ & 0.3995 \\
\hline Mechanic's hands & $35(17.4)$ & $50(42.7)$ & $<0.0001$ \\
\hline Raynaud \\
phenomenon & $70(35.2)$ & $34(29.8)$ & \\
\hline Skin ulcers & $11(5.5)$ & $49(41.5)$ & $12(10.2)$ \\
\hline Calcinosis & $4(2)$ & & \\
\hline & & & \\
\hline
\end{tabular}

\section{Muscle}

\begin{tabular}{llll}
\hline Proximal weakness & $180(90)$ & $35(30.7)$ & $<0.0001$ \\
\hline Psoas MRC $\leq 3$ & $107(57.53)$ & $8(8.2)$ & $<0.0001$ \\
\hline Increased CK level & $190(94.5)$ & $46(41.4)$ & $<0.0001$ \\
\hline CK level >800 IU/L & $162(80.6)$ & $13(10.7)$ & $<0.0001$ \\
\hline Myositis on biopsy & $170(90.9)$ & $30(55.6)$ & $<0.0001$ \\
\hline Joints & & & \\
\hline
\end{tabular}

\begin{tabular}{llll}
\hline Arthritis/arthralgia & $92(45.8)$ & $80(69)$ & $<0.0001$ \\
\hline Lungs & & & \\
\hline Dyspnea & $137(70.3)$ & $80(66.7)$ & 0.5871 \\
\hline ILD & $90(46.4)$ & $91(76.5)$ & $<0.0001$ \\
\hline Malignancy & $24(12)$ & $9(7.6)$ & 0.296 \\
\hline Death & $13(6.8)$ & $33(27.3)$ & $<0.0001$
\end{tabular}

Abbreviations: $\mathrm{CK}=$ creatine kinase; $\mathrm{DM}=$ dermatomyositis; ILD = interstitial lung disease; MRC = Medical Research Council scale. Values are $\mathrm{n}(\%)$.

0.0001). Comparing patients in the rheumatic cluster to those in the vasculopathic cluster, it appeared that the prognosis was better (very good) in the rheumatic cluster than in the vasculopathic cluster $(p=0.01)$.

Finally, we aimed to easily position a participant in one of the 3 clusters. Classification and regression tree analysis was used as a predictive model to determine the items permitting us to classify a patient (figure $2 \mathrm{~B}$ ). Because we aimed to predict patient outcome, the variables related to obvious severity were removed (RP-ILD and ICU). The models including 3 variables Raynaud phenomenon, arthralgia/arthritis, and sex permits $83.3 \%$ correct estimation. Of note, adding the variable RP-ILD permits us to reach $91.6 \%$ correct estimation.

\section{Comparison of anti-MDA5+ vs anti-MDA5- patients}

Because we observed the different subgroups of antiMDA5+ patients, we aimed to verify if anti-MDA5+ disease remains a separate entity within myositis. We compared anti-MDA5+ patients $(\mathrm{n}=121)$ to anti-MDA5- myositis patients $(\mathrm{n}=201)($ table 2$)$.

Compared to anti-MDA5- patients, anti-MDA5+ patients were more frequently African, more frequently had a DM skin rash, skin ulcers, calcinosis, mechanic's hands, ILD, and arthralgia/arthritis, and had a higher mortality rate (table 2). Anti-MDA5- patients had more severe myositis (based on muscle weakness and CK level).

Next, we performed an unsupervised hierarchical clustering analysis in a large group of patients with myositis (antiMDA5+ and anti-MDA5- patients; $n=274 / 322$ ) with 20 variables, including long-term mortality (table e-2, doi.org/ 10.5061 /dryad.t39c4k1), but importantly not including antiMDA5 antibody status. We clearly observed 2 clusters (figure 3 and figure e-1, doi.org/10.5061/dryad.t39c4k1). The hierarchical tree positioned on the factorial map showed that cluster 2 regrouped mainly anti-MDA5+ patients $(87.5 \%$; $\mathrm{n}=$ $84 / 96$ vs $7.3 \%$; $n=13 / 178$; $p<0.0001$ ) after having positioned the variable anti-MDA5. The anti-MDA5 antibody delineates an independent subgroup of patients from a large cohort of patients with myositis.

\section{Discussion}

We report the phenotype of a large group of anti-MDA5+ patients. Overall, our observation confirmed previous studies showing that anti-MDA5+ patients present a DM skin rash with frequent signs of skin vasculopathy, ${ }^{3}$ frequent arthralgia/ arthritis, ${ }^{4}$ and ILD with a high mortality rate. ${ }^{1}$

Using unsupervised analyses, we observed for the first time 3 distinct subgroups with different prognoses. The RP-ILD cluster with severe lung involvement and a poor prognosis corresponds to well-recognized anti-MDA5+ RP-ILD. ${ }^{1,5}$ In addition, we were able to isolate 2 new forms: anti-MDA5+ rheumatic DM, with a good prognosis, and anti-MDA5+ vasculopathic DM, with an intermediate prognosis. The algorithm decisional algorithm showed that only 3 variables (Raynaud phenomenon, arthralgia/arthritis, and sex) are good predictors for cluster appurtenance. 
Figure 1 Unsupervised analysis of anti-melanoma differentiation-associated gene 5 antibody-positive (anti-MDA5+) patients
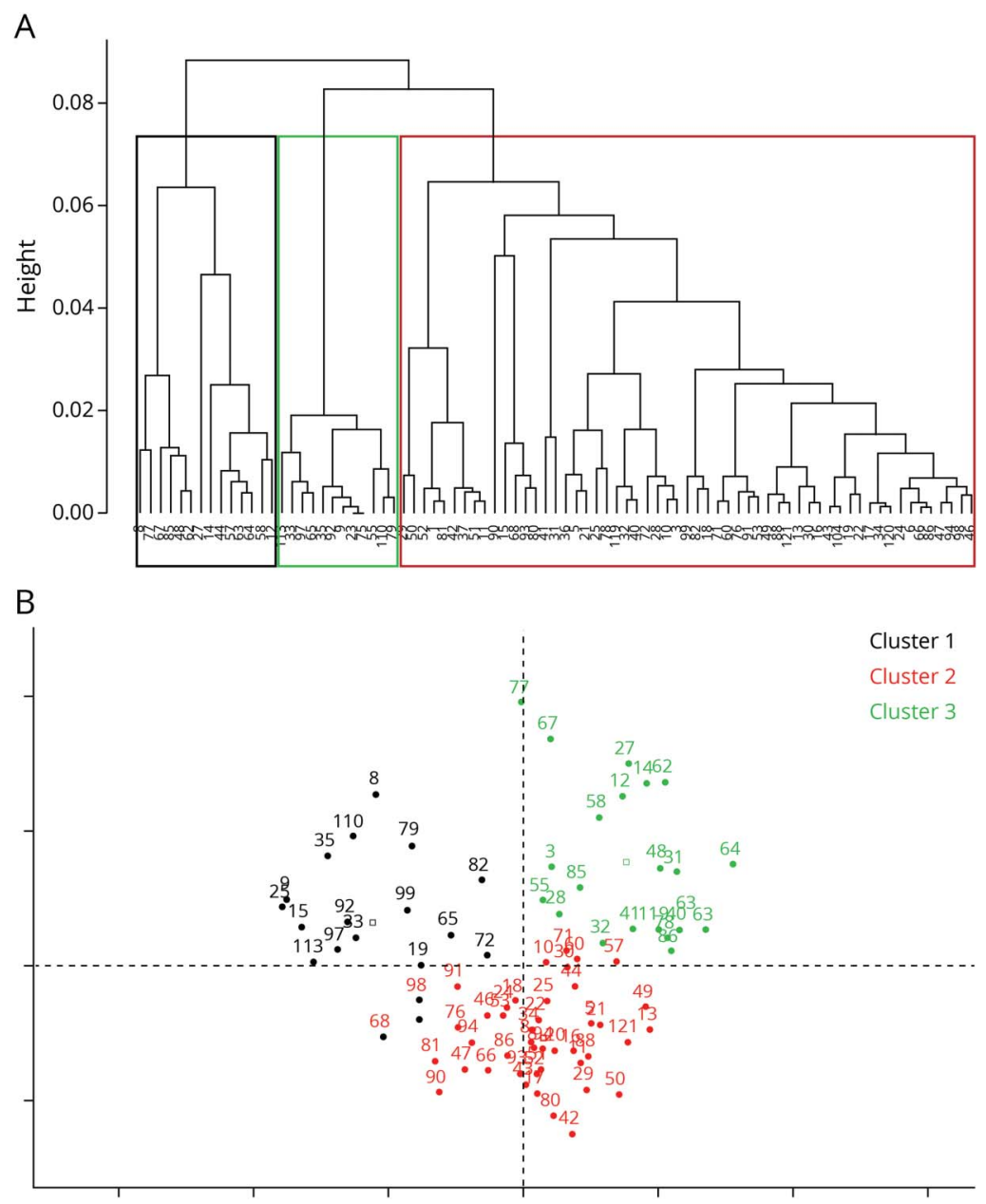

(A) The hierarchical cluster analysis of anti-MDA5+ patients showed 3 clusters (the variables included in the unsupervised analysis were sex, ethnicity, skin changes, typical dermatomyositis skin rash, mechanic's hands, skin ulcers, calcinosis, digital necrosis, sclerosis, Raynaud phenomenon, abnormal creatine kinase [CK] level, CK level, proximal muscle weakness, manual muscle testing score of the psoas [Medical Research Council score], arthritis/arthralgia, synovitis, dyspnea, interstitial lung disease [ILD], rapidly progressive ILD, resuscitation, deterioration of general status, malignancy, intensive care unit admission, malignancy within 3 years before or after the myositis diagnosis, and early mortality). (B) Multiple correspondence analysis confirmed the presence of 3 groups of anti-MDA5+ patients. All above-mentioned variables except intensive rapidly progressive ILD, care unit admission, and mortality were included in the classification algorithm regression tree analysis.

Figure 2 Anti-melanoma differentiation-associated gene 5 antibody-positive (anti-MDA5+) prognosis

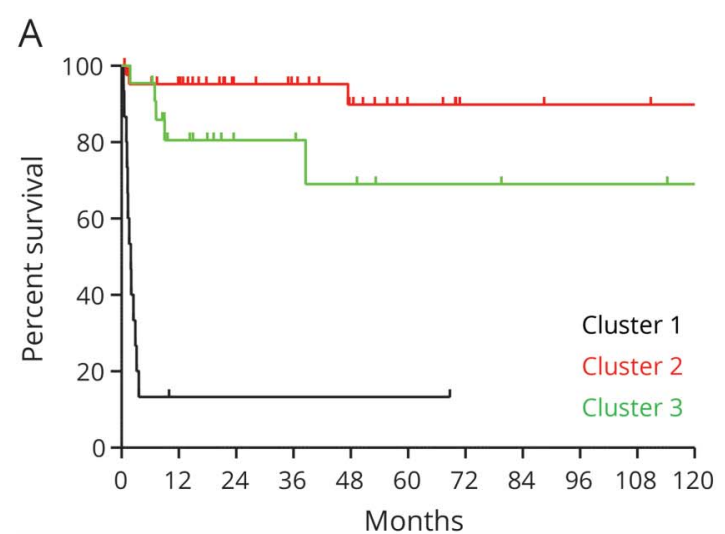

B

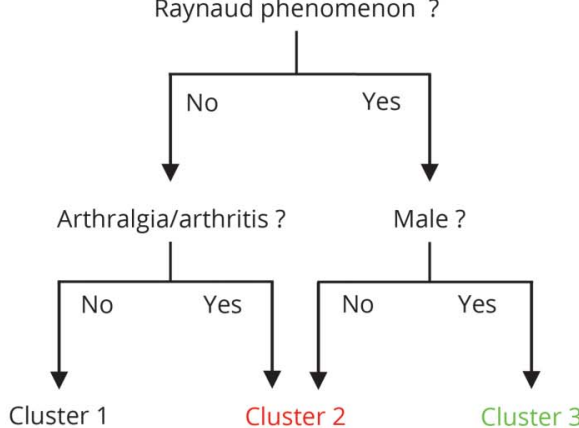

(A) The survival curves showed that cluster 1 (black) had a poor prognosis, cluster 2 (red) had a good prognosis, and cluster 3 (green) had a mild prognosis. (B) Pruned model of prediction without obvious signs of severity (the variables included in the classification algorithm regression tree analysis did not encompass obvious signs of severity [rapidly progressive interstitial lung disease (ILD), intensive care unit admission, and mortality], sex, ethnicity, skin changes, typical dermatomyositis skin rash, mechanic's hands, skin ulcers, calcinosis, digital necrosis, sclerosis, Raynaud phenomenon, abnormal creatine kinase [CK] level, CK level, proximal muscle weakness, manual muscle testing score of the psoas [Medical Research Council score], arthritis/arthralgia, synovitis, dyspnea, ILD, deterioration of the general status, malignancy, and malignancy within 3 years before or after the myositis diagnosis). 
Figure 3 Unsupervised analysis of anti-melanoma differentiation-associated gene 5 antibody-positive (anti-MDA5+) and anti-MDA5- patients
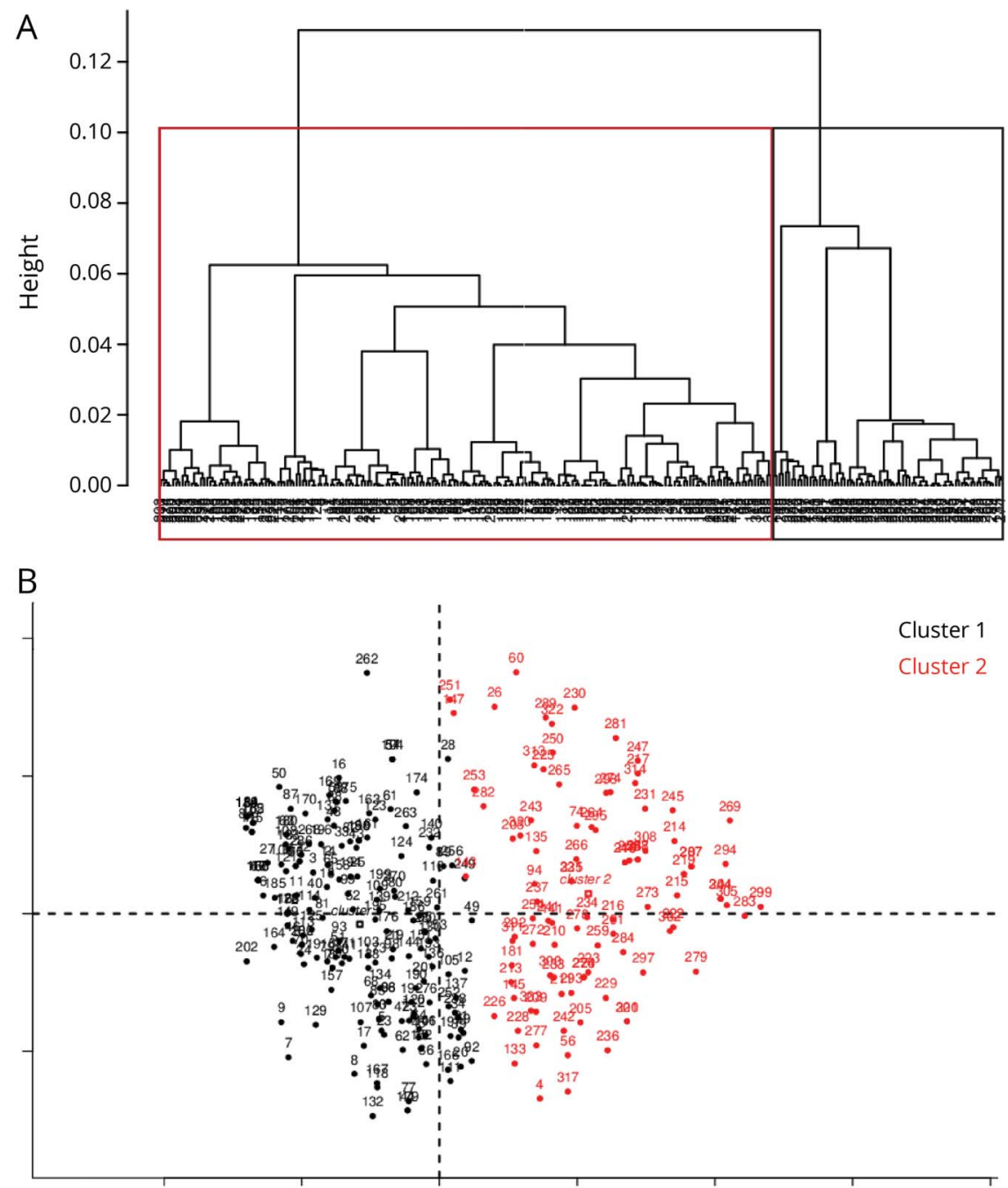

(A) Hierarchical cluster analysis of anti-MDA5+ patients and anti-MDA5- myositis patients without including the anti-MDA5 antibody status as variable (the variables included for the unsupervised analysis were sex, ethnicity, proximal muscle weakness, abnormal creatine kinase [CK] level, CK level, skin changes, typical dermatomyositis skin rash, mechanic's hands, skin ulcers, calcinosis, Raynaud phenomenon, arthritis/arthralgia, dyspnea, interstitial lung disease, and malignancy within 3 years before or after the myositis diagnosis). The analysis permitted the identification 2 main clusters. (B) Using multiple correspondence analysis, both clusters were positioned on the factor map of individuals, which confirmed that patients were segregated into 2 groups. When the variable anti-MDA5 was next positioned, it appeared that cluster 2 was mainly composed of anti-MDA5+ patients (87.1\%).

These observations and the large spectrum of disease manifestations suggest that the so-called anti-MDA5+DM is rather a systemic syndrome (anti-MDA5+ syndrome) than a musculocutaneous disease.

This finding underlines the importance of anti-MDA5 antibody screening in patients with seronegative polyarthritis and patients with interstitial pneumonia, with a suspicion of autoimmune features, ${ }^{11}$ or ICU patients with acute respiratory distress syndrome of unknown origin. The prognosis related to the different clusters is also important regarding the treatment strategy and may suggest different pathophysiologic mechanisms.

The comparison of anti-MDA5+ patients with a large cohort of MDA5- patients showed that anti-MDA5+ syndrome remains a separate entity. Using unsupervised clustering analysis, we showed that the anti-MDA5+ antibody was independently and strongly associated with this phenotype. This result emphasizes the crucial role of myositis-specific antibodies to diagnose and delineate a subgroup of patients. However, the term myositisspecific antibody seems inappropriate, because many antiMDA5+ patients are amyopathic.

The nationwide retrospective cohort study design we used is the main limitation of our work. The low frequency of the reported rheumatologic signs in the RP-ILD cluster could be due to a detection bias since the majority of patients were in the ICU. Nevertheless, patients in the RP-ILD cluster were also characterized by an increased CK level, whereas this was not the case for patients with the rheumatologic form in cluster 2 .

Together, these data show that anti-MDA5+ patients are a distinct group from patients with myositis and have a systemic syndrome composed of 3 different entities with different prognoses. The anti-MDA5+ antibody is a key biomarker to define this syndrome. 
Study funding

No targeted funding reported.

\section{Disclosure}

The authors report no relevant disclosures. Go to Neurology. org/ $\mathrm{N}$ for full disclosures.

\section{Publication history}

Received by Neurology February 14, 2019. Accepted in final form December 12, 2019.

\section{Appendix Authors}

\begin{tabular}{|c|c|c|}
\hline Name & Location & Contribution \\
\hline $\begin{array}{l}\text { Yves } \\
\text { Allenbach, } \\
\text { MD, PhD }\end{array}$ & $\begin{array}{l}\text { Sorbonne Université, } \\
\text { Paris }\end{array}$ & $\begin{array}{l}\text { Designed and } \\
\text { conceptualized the study, } \\
\text { analyzed the data, drafted } \\
\text { the manuscript }\end{array}$ \\
\hline $\begin{array}{l}\text { Yurdagul } \\
\text { Uzunhan, } \\
\text { MD, PhD }\end{array}$ & $\begin{array}{l}\text { APHP, Avicenne hospital, } \\
\text { INSERM U1272, Université } \\
\text { Sorbonne Paris Nord, } \\
\text { Bobigny }\end{array}$ & $\begin{array}{l}\text { Designed and } \\
\text { conceptualized the study, } \\
\text { analyzed the data, drafted } \\
\text { the } \\
\text { manuscript }\end{array}$ \\
\hline $\begin{array}{l}\text { Ségolène } \\
\text { Toquet, MD }\end{array}$ & $\begin{array}{l}\text { Sorbonne Université, } \\
\text { Paris }\end{array}$ & $\begin{array}{l}\text { Major role in data } \\
\text { acquisition, revised the } \\
\text { manuscript for intellectual } \\
\text { content }\end{array}$ \\
\hline $\begin{array}{l}\text { Gaëlle } \\
\text { Leroux, MD }\end{array}$ & $\begin{array}{l}\text { Sorbonne Université, } \\
\text { Paris }\end{array}$ & $\begin{array}{l}\text { Major role in data } \\
\text { acquisition, revised the } \\
\text { manuscript for intellectual } \\
\text { content }\end{array}$ \\
\hline $\begin{array}{l}\text { Laure Gallay, } \\
\text { MD }\end{array}$ & Lyon Université & $\begin{array}{l}\text { Major role in data } \\
\text { acquisition, revised the } \\
\text { manuscript for intellectual } \\
\text { content }\end{array}$ \\
\hline $\begin{array}{l}\text { Alicia } \\
\text { Marquet, MD }\end{array}$ & Lyon Université & $\begin{array}{l}\text { Major role in data } \\
\text { acquisition }\end{array}$ \\
\hline $\begin{array}{l}\text { Alain Meyer, } \\
\text { MD, PhD }\end{array}$ & Strasbourg Université & $\begin{array}{l}\text { Major role in data } \\
\text { acquisition }\end{array}$ \\
\hline $\begin{array}{l}\text { Constance } \\
\text { Guillaud, MD }\end{array}$ & $\begin{array}{l}\text { Paris Est Université, } \\
\text { Créteil }\end{array}$ & $\begin{array}{l}\text { Major role in data } \\
\text { acquisition }\end{array}$ \\
\hline $\begin{array}{l}\text { Nicolas Limal, } \\
\text { MD }\end{array}$ & $\begin{array}{l}\text { Paris Est Université, } \\
\text { Créteil }\end{array}$ & $\begin{array}{l}\text { Major role in data } \\
\text { acquisition }\end{array}$ \\
\hline $\begin{array}{l}\text { Frédéric } \\
\text { Gagnadoux, } \\
\text { MD, PhD }\end{array}$ & Angers Université & $\begin{array}{l}\text { Major role in data } \\
\text { acquisition }\end{array}$ \\
\hline $\begin{array}{l}\text { Baptiste } \\
\text { Hervier, MD, } \\
\text { PhD }\end{array}$ & $\begin{array}{l}\text { Sorbonne Université, } \\
\text { Paris }\end{array}$ & $\begin{array}{l}\text { Major role in data } \\
\text { acquisition }\end{array}$ \\
\hline $\begin{array}{l}\text { Raphaël } \\
\text { Borie, MD, } \\
\text { PhD }\end{array}$ & $\begin{array}{l}\text { Paris Diderot Université, } \\
\text { Paris }\end{array}$ & $\begin{array}{l}\text { Major role in data } \\
\text { acquisition }\end{array}$ \\
\hline $\begin{array}{l}\text { Christophe } \\
\text { Deligny, MD, } \\
\text { PhD }\end{array}$ & $\begin{array}{l}\text { Centre Hospitalier } \\
\text { Universitaire, Martinique }\end{array}$ & $\begin{array}{l}\text { Major role in data } \\
\text { acquisition }\end{array}$ \\
\hline $\begin{array}{l}\text { Benjamin } \\
\text { Terrier, MD, } \\
\text { PhD }\end{array}$ & $\begin{array}{l}\text { Descartes Université, } \\
\text { Paris }\end{array}$ & $\begin{array}{l}\text { Major role in data } \\
\text { acquisition }\end{array}$ \\
\hline $\begin{array}{l}\text { Alice } \\
\text { Berezne, MD }\end{array}$ & Hôpital Annecy, Annecy & $\begin{array}{l}\text { Major role in data } \\
\text { acquisition }\end{array}$ \\
\hline
\end{tabular}

Appendix (continued)

\begin{tabular}{|c|c|c|}
\hline Name & Location & Contribution \\
\hline $\begin{array}{l}\text { Sylvain } \\
\text { Audia, MD, } \\
\text { PhD }\end{array}$ & $\begin{array}{l}\text { Université Bourgogne } \\
\text { Franche Comté, Dijon }\end{array}$ & $\begin{array}{l}\text { Major role in data } \\
\text { acquisition }\end{array}$ \\
\hline $\begin{array}{l}\text { Nicolas } \\
\text { Champtiaux, } \\
\text { MD, PhD }\end{array}$ & $\begin{array}{l}\text { Sorbonne Université, } \\
\text { Paris }\end{array}$ & $\begin{array}{l}\text { Major role in data } \\
\text { acquisition }\end{array}$ \\
\hline $\begin{array}{l}\text { Hervé } \\
\text { Devilliers, } \\
\text { MD, PhD }\end{array}$ & $\begin{array}{l}\text { Université Bourgogne } \\
\text { Franche Comté, Dijon }\end{array}$ & $\begin{array}{l}\text { Major role in data } \\
\text { acquisition }\end{array}$ \\
\hline $\begin{array}{l}\text { Nicol } \\
\text { Voernmans, } \\
\text { MD }\end{array}$ & $\begin{array}{l}\text { Radboud Université, } \\
\text { Nijmegen }\end{array}$ & $\begin{array}{l}\text { Major role in data } \\
\text { acquisition }\end{array}$ \\
\hline $\begin{array}{l}\text { Elizabeth } \\
\text { Diot, MD }\end{array}$ & Tour Université, Tour & $\begin{array}{l}\text { Major role in data } \\
\text { acquisition }\end{array}$ \\
\hline $\begin{array}{l}\text { Amélie } \\
\text { Servettaz, } \\
\text { MD, PhD }\end{array}$ & Reims Université & $\begin{array}{l}\text { Major role in data } \\
\text { acquisition }\end{array}$ \\
\hline $\begin{array}{l}\text { Thierry } \\
\text { Marhadour, } \\
\text { MD }\end{array}$ & $\begin{array}{l}\text { Bretagne Université, } \\
\text { Reims }\end{array}$ & $\begin{array}{l}\text { Major role in data } \\
\text { acquisition }\end{array}$ \\
\hline $\begin{array}{l}\text { Vincent } \\
\text { Castelain, } \\
\text { MD, PhD }\end{array}$ & Strasbourg Université & $\begin{array}{l}\text { Major role in data } \\
\text { acquisition }\end{array}$ \\
\hline $\begin{array}{l}\text { Sébastien } \\
\text { Humbert, MD }\end{array}$ & Besançon Université & $\begin{array}{l}\text { Major role in data } \\
\text { acquisition }\end{array}$ \\
\hline $\begin{array}{l}\text { Claire } \\
\text { Blanchard- } \\
\text { Delaunay, MD }\end{array}$ & Niort Hôpital & $\begin{array}{l}\text { Major role in data } \\
\text { acquisition }\end{array}$ \\
\hline $\begin{array}{l}\text { Nathalie } \\
\text { Tieulie, MD, } \\
\text { PhD }\end{array}$ & Nice Université & $\begin{array}{l}\text { Major role in data } \\
\text { acquisition }\end{array}$ \\
\hline $\begin{array}{l}\text { Pierre } \\
\text { Charles, MD }\end{array}$ & $\begin{array}{l}\text { Institut Mutualiste } \\
\text { Montsouris, Paris }\end{array}$ & $\begin{array}{l}\text { Major role in data } \\
\text { acquisition }\end{array}$ \\
\hline $\begin{array}{l}\text { Magdalena } \\
\text { Gerin, MD }\end{array}$ & Saint Denis Université & $\begin{array}{l}\text { Major role in data } \\
\text { acquisition }\end{array}$ \\
\hline $\begin{array}{l}\text { Arsène } \\
\text { Mekinian, } \\
\text { MD, PhD }\end{array}$ & $\begin{array}{l}\text { Sorbonne Université, } \\
\text { Paris }\end{array}$ & $\begin{array}{l}\text { Major role in data } \\
\text { acquisition }\end{array}$ \\
\hline $\begin{array}{l}\text { Pascaline } \\
\text { Priou, MD }\end{array}$ & Angers Université & $\begin{array}{l}\text { Major role in data } \\
\text { acquisition }\end{array}$ \\
\hline $\begin{array}{l}\text { Jean Claude } \\
\text { Meurice, MD, } \\
\text { PhD }\end{array}$ & Poitier Université & $\begin{array}{l}\text { Major role in data } \\
\text { acquisition }\end{array}$ \\
\hline $\begin{array}{l}\text { Abdellatif } \\
\text { Tazi, MD, PhD }\end{array}$ & Paris Diderot Université & $\begin{array}{l}\text { Major role in data } \\
\text { acquisition }\end{array}$ \\
\hline $\begin{array}{l}\text { Vincent } \\
\text { Cottin, MD, } \\
\text { PhD }\end{array}$ & Lyon Université & $\begin{array}{l}\text { Major role in data } \\
\text { acquisition }\end{array}$ \\
\hline $\begin{array}{l}\text { Makoto } \\
\text { Miyara, MD, } \\
\text { PhD }\end{array}$ & $\begin{array}{l}\text { Sorbonne Université, } \\
\text { Paris }\end{array}$ & $\begin{array}{l}\text { Major role in data } \\
\text { acquisition }\end{array}$ \\
\hline $\begin{array}{l}\text { Benjamin } \\
\text { Grange, MD }\end{array}$ & $\begin{array}{l}\text { Sorbonne Université, } \\
\text { Paris }\end{array}$ & $\begin{array}{l}\text { Interpreted the data and } \\
\text { statistical analysis }\end{array}$ \\
\hline $\begin{array}{l}\text { Dominique } \\
\text { Israël-Biet, } \\
\text { MD, PhD }\end{array}$ & $\begin{array}{l}\text { Descartes Université, } \\
\text { Paris }\end{array}$ & $\begin{array}{l}\text { Major role in data } \\
\text { acquisition }\end{array}$ \\
\hline
\end{tabular}


Appendix (continued)

\begin{tabular}{|c|c|c|}
\hline Name & Location & Contribution \\
\hline $\begin{array}{l}\text { Sophie Phin- } \\
\text { Huynh, MD }\end{array}$ & $\begin{array}{l}\text { Sainte Camille Hôpital, } \\
\text { Bry-sur-Marne }\end{array}$ & $\begin{array}{l}\text { Major role in data } \\
\text { acquisition }\end{array}$ \\
\hline $\begin{array}{l}\text { Camille Bron, } \\
\text { MD }\end{array}$ & $\begin{array}{l}\text { Saint Quentin Université, } \\
\text { Suresnes }\end{array}$ & $\begin{array}{l}\text { Major role in data } \\
\text { acquisition }\end{array}$ \\
\hline $\begin{array}{l}\text { Luc De Saint } \\
\text { Martin, MD }\end{array}$ & Brest Université & $\begin{array}{l}\text { Major role in data } \\
\text { acquisition }\end{array}$ \\
\hline $\begin{array}{l}\text { Nicole } \\
\text { Fabien, MD }\end{array}$ & Lyon Université & $\begin{array}{l}\text { Major role in data } \\
\text { acquisition }\end{array}$ \\
\hline $\begin{array}{l}\text { Kubéraka } \\
\text { Mariampillai, } \\
\text { MD }\end{array}$ & $\begin{array}{l}\text { Sorbonne Université, } \\
\text { Paris }\end{array}$ & $\begin{array}{l}\text { Interpreted the data and } \\
\text { statistical analysis, revised } \\
\text { the manuscript for } \\
\text { intellectual content }\end{array}$ \\
\hline $\begin{array}{l}\text { Hilario } \\
\text { Nunes, MD, } \\
\text { PhD }\end{array}$ & $\begin{array}{l}\text { APHP, Avicenne hospital, } \\
\text { INSERM U1272, Université } \\
\text { Sorbonne Paris Nord, } \\
\text { Bobigny }\end{array}$ & $\begin{array}{l}\text { Major role in data } \\
\text { acquisition, interpreted the } \\
\text { data, revised the manuscript } \\
\text { for intellectual content }\end{array}$ \\
\hline $\begin{array}{l}\text { Olivier } \\
\text { Benveniste, } \\
\text { MD, PhD }\end{array}$ & $\begin{array}{l}\text { Sorbonne Université, } \\
\text { Paris }\end{array}$ & $\begin{array}{l}\text { Major role in data } \\
\text { acquisition, interpreted the } \\
\text { data, revised the } \\
\text { manuscript for intellectual } \\
\text { content }\end{array}$ \\
\hline
\end{tabular}

\section{References}

1. Hamaguchi Y, Kuwana M, Hoshino K, et al. Clinical correlations with dermatomyositis-specific autoantibodies in adult Japanese patients with dermatomyositis: a multicenter cross-sectional study. Arch Dermatol 2011;147:391-398.

2. Benveniste O, Stenzel W, Allenbach Y. Advances in serological diagnostics of inflammatory myopathies. Curr Opin Neurol 2016;29:662-673.

3. Fiorentino D, Chung L, Zwerner J, Rosen A, Casciola-Rosen L. The mucocutaneous and systemic phenotype of dermatomyositis patients with antibodies to MDA5 (CADM-140): a retrospective study. J Am Acad Dermatol 2011;65:25-34.

4. Hall JC, Casciola-Rosen L, Samedy LA, et al. Anti-melanoma differentiation-associated protein 5-associated dermatomyositis: expanding the clinical spectrum: clinical features of anti-MDA-5-positive patients. Arthritis Care Res 2013;65:1307-1315.

5. Sato S, Hoshino K, Satoh T, et al. RNA helicase encoded by melanoma differentiationassociated gene 5 is a major autoantigen in patients with clinically amyopathic dermatomyositis: association with rapidly progressive interstitial lung disease. Arthritis Rheum 2009;60:2193-2200.

6. Hoogendijk JE, Amato AA, Lecky BR, et al. ENMC international workshop: trial design in adult idiopathic inflammatory myopathies, with the exception of inclusion body myositis, 10-12 October 2003, Naarden, The Netherlands. Neuromuscul Disord 2004;14:337-345.

7. Sontheimer RD. Would a new name hasten the acceptance of amyopathic dermatomyositis (dermatomyositis siné myositis) as a distinctive subset within the idiopathic inflammatory dermatomyopathies spectrum of clinical illness? J Am Acad Dermatol 2002;46:626-636.

8. Bohan A, Peter JB. Polymyositis and dermatomyositis (first of two parts). N Engl J Med 1975;292:344-347.

9. Mariampillai K, Granger B, Amelin D, et al. Development of a new classification system for idiopathic inflammatory myopathies based on clinical manifestations and myositis-specific autoantibodies. JAMA Neurol 2018;75:1528-1537.

10. Lebart L, Morineau A, Warwick KM. Multivariate Descriptive Statistical Analysis (Correspondence Analysis and Related Techniques for Large Matrices). Chichester: Wiley; 1984.

11. Fischer A, Antoniou KM, Brown KK, et al. An official European Respiratory Society/ American Thoracic Society research statement: interstitial pneumonia with autoimmune features. Eur Respir J 2015;46:976-987. 


\section{Neurology}

\section{Different phenotypes in dermatomyositis associated with anti-MDA5 antibody: Study of 121 cases}

Yves Allenbach, Yurdagul Uzunhan, Ségolène Toquet, et al.

Neurology published online June 2, 2020

DOI 10.1212/WNL.0000000000009727

This information is current as of June 2, 2020

\section{Updated Information \&} Services

Permissions \& Licensing

Reprints including high resolution figures, can be found at: http://n.neurology.org/content/early/2020/06/02/WNL.0000000000009 727.full

Information about reproducing this article in parts (figures,tables) or in its entirety can be found online at:

http://www.neurology.org/about/about_the_journal\#permissions

Information about ordering reprints can be found online: http://n.neurology.org/subscribers/advertise

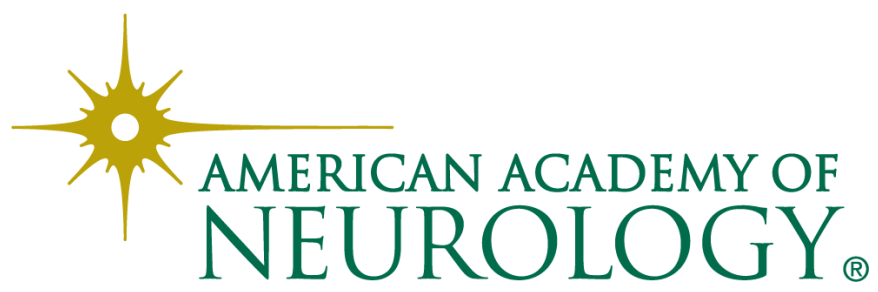

